\title{
Integrated management of Ramularia blight (Ramularia foeniculi ) in fennel
}

\section{Arvindkumar M. Amin}

Seed Spices Research Station, S.D. Agricultural University, Jagudan, Mehsana-384460 (Gujarat), India

\section{Nareshkumar R. Patel}

Seed Spices Research Station, S.D. Agricultural University, Jagudan, Mehsana-384460 (Gujarat), India

\section{Babubhai G. Prajapati}

Seed Spices Research Station, S.D. Agricultural University, Jagudan, Mehsana-384460 (Gujarat), India

\section{Rakesh Kumar Jaiman*}

College of Horticulture, S.D. Agricultural University, Jagudan, Mehsana-384460 (Gujarat), India

Shalish B. Gondaliya

Central Laboratory, S.D. Agricultural University, Sardarkrushinagar, Banaskantha-385506 (Gujarat), India

*Corresponding author. Email: jaimanrs74@gmail.com

\section{Article Info}

https://doi.org/10.31018/

jans.v13i1.2503

Received: January 21, 2021

Revised: February 27, 2021

Accepted: March 3, 2021

\section{How to Cite}

Amin, A. M. et al. (2021). Integrated management of Ramularia blight (Ramularia foeniculi ) in fennel. Journal of Applied and Natural Science, 13(1): 191 - 196. https://doi.org/10.31018/jans.v13i1.2503

\begin{abstract}
Ramularia blight, caused by Ramularia foeniculi Sybille's a highly destructive fennel disease and may cause complete failure of the crop. The use of chemicals especially mancozeb to manage Ramularia blight increases the load of residues in seed and reduces the export and market price. Removal of lower yellow leaves would not only help in reducing the load of Ramularia pathogen but, also increase the aeration in fennel crop. To manage this disease, field trial was conducted for three consecutive kharif seasons (2017-18, 2018-19 \& 2019-20) with agronomical practices i.e. removal of lower yellow leaves at different stages and different spraying schedules of chlorothalonil 75WP. Removal of lower yellow leaves at $50 \%$ flowering stage and grain filling stage with two sprays of chlorothalonil 75WP @ $0.15 \%(20 \mathrm{~g} / 10$ lit. water $)$ first spray at just appearance of disease and second spray at 15 days after first spray was found effective not only in terms of management of disease (10.91\% disease incidence), yield (2078 kg/ha) and quality aspects but also reduced the load of fungicide on seed which promote the export. Thus, limited use (2 sprays) of chlorothalonil with the removal of lower yellow leaves helps to meet out the quality standards for export promotion with respect to residual limits in the said commodity.
\end{abstract}

Keywords: Fennel, Integrated management, Residual limit, Ramularia blight

\section{INTRODUCTION}

Fennel (Foeniculum vulgare Mill; Family: Apiaceae) a seed spice is native of Southern Europe and Mediterranean area and widely cultivated in the temperate and subtropical regions of the world. The major fennel growing countries are France, Germany, Romania, Russia, Italy, India and the US and Gujarat, Rajasthan, Karnataka, Maharastra, UP, Punjab and Bihar are major cultivated states in India. The share of Gujarat state in area and production of fennel is 62.5 and 74.6 per cent, respectively. (Anonymous, 2019). The productivity of the fennel in Gujarat is also the highest in the country. Dry and cool weather during the seed set increases fennel seed yield as well as the quality of the produce. Fennel can be cultivated in all types of soils that are rich in organic matter especially black cotton soil and loamy soil containing lime with having 6.5 to $8.0 \mathrm{pH}$ and require $15-20^{\circ} \mathrm{C}$ temperature for vegetative growth. Fennel is rich in vitamin $A$ and it also contains calcium, 
phosphorous and potassium in lower amount (Abubacker, 2011). Fennel has a great medicinal value due to odour produced by anethole.

Fennel seed has digestive, stomachic, carminative, stimulant, appetizer properties and used for control of diseases e. i. cholera, biliousness, dysentery, diarrhoea, cough, cold, constipation and ailment of chest, lungs and kidney. The production of fennel was negatively influenced by diseases caused by pathogens. (Mukerji and Basin,1986). Ramularia blight may cause complete failure of crop if proper precautionary measures are not taken. The spraying of mancozeb 75WP @ $0.2 \%$ or chlorothalonil 75WP @ $0.15 \%$ is only the chemical remedy for the management of Ramularial blight (Patel and Patel, 2008; Patel et al., 2016). The injudicious use of chemicals to combat Ramularia blight increases the load of residues in fennel seed and ultimately reduces the export potential and market price. Lower yellow leaves increase the humidity in microclimate surrounding crop, which is favourable for the development of Ramularia blight and matured yellow leaves serves as a reservoir for pathogen as a primary source of inoculums of disease (Katan, 2010). However, the systemic study was not done earlier with respect to removal of leaves in combination to fungicide. The experiment was planned with an objective of minimizing the residue level of fungicide in fennel.

\section{MATERIALS AND METHODS}

A field experiment was conducted at Centre for Research on Seed Spices, S. D. Agricultural University, Jagudan, Gujarat, India in a randomized block design with four replications during kharif 2017-18, 2018-19 and 2019-20. The Gujarat Fennel-12 (GF-12) seedlings were transplanted in the month of August at a distance of $90 \mathrm{~cm} \times 60 \mathrm{~cm}$ in a plot size $5.4 \mathrm{~m} \times 6.0 \mathrm{~m}$. Different treatments viz., $\mathrm{T}_{1}$ - removal of lower yellow leaves at 50 $\%$ flowering stage, $\mathrm{T}_{2}$ - removal of lower yellow leaves at grain filling stage, $\mathrm{T}_{3}$ - removal of lower yellow leaves at $50 \%$ flowering stage and grain filling stage, $\mathrm{T}_{4}$ - removal of lower yellow leaves at $50 \%$ flowering stage and two sub sequent foliar sprays of chlorothalonil 75WP @ $0.15 \%$ (20 g/ 10 lit. water) $\mathrm{T}_{5}$ - removal of lower yellow leaves at $50 \%$ flowering stage and grain filling stage and one spray of chlorothalonil 75WP @ 0.15\% (20 g/ 10 lit. water), $\mathrm{T}_{6}$ - removal of lower yellow leaves at 50 $\%$ flowering stage and grain filling stage and two sprays of chlorothalonil 75WP @ 0.15\% (20 g/ 10 lit. water), $\mathrm{T}_{7}$ - three foliar sprays of chlorothalonil 75WP @ $0.15 \%$ (20 g/ 10 lit. water) and $\mathrm{T}_{8}$ - untreated control. The efficacy of chlorothalonil along with cultural practices (Removal of yellow leave) was compared with Untreated Control (without spray). The first spray at incitation of disease and subsequent sprays were applied at $10 / 15$ days interval.
The observation on the disease intensity was recorded after 10 days of last spray from 20 randomly selected plants from each plots using 0-5 scale as: $0=$ No incidence/Healthy; 1 = Symptoms on leaf tip and leaves only; 2 = Symptoms on leaves and petiole; 3 = Symptoms on leaves, petiole and stem; 4 = Symptoms on leaves, stem and inflorescence; $5=$ Symptoms on leaves, stem, inflorescence including seeds. Based on these observations, per cent disease intensity (PDI) of the disease was worked out using the formula described by Datar and Mayee ( 1981). The fennel seed yield was recorded from individual plots and converted on hectare basis.

\section{RESULTS AND DISCUSSION}

A significant difference in treatments was observed in per cent disease incidence in pooled and individual years. (Table1). The minimum PDI (10.91\%) of Ramularia blight was observed in $\mathrm{T}_{6}$ i.e. removal of lower yellow leaves at $50 \%$ flowering stage and grain filling stage and two sprays of chlorothalonil 75WP @ 0.15\% $\left(20 \mathrm{~g} / 10\right.$ lit. water) which was at par with treatments $T_{7}$ i.e. three foliar sprays of chlorothalonil 75WP @ 0.15\% (20 g/ 10 lit. water) during second year and pooled data. In the year 2017-18 and 2019-2020 lower disease intensity was observed in $\mathrm{T}_{6}$ i.e removal of lower yellow leaves at $50 \%$ flowering stage and grain filling stage and two sprays of chlorothalonil 75WP @ 0.15\% (20 g/ 10 lit. water) and were at par with treatments $\mathrm{T}_{7}$ i.e three foliar sprays of chlorothalonil 75WP @ 0.15\% (20 $\mathrm{g} / 10$ lit. water) , $\mathrm{T}_{4}$ i.e removal of lower yellow leaves at $50 \%$ flowering stage and two subsequent foliar sprays of chlorothalonil 75WP @ 0.15\% (20 g/ 10 lit. water) and $\mathrm{T}_{5}$ i.e Removal of lower yellow leaves at $50 \%$ flowering stage and grain filling stage and one spray of chlorothalonil 75WP @ 0.15\%(Table 1).

Different treatments on fennel seed yield were found significant at $5 \%$ level of significance during individual years and pooled also (Table 2). All the treatments were found effective and producing significantly higher yield than the untreated control. Significantly higher yield $\left(2078 \mathrm{~kg} / \mathrm{ha}\right.$ ) was recorded in treatment $\mathrm{T}_{6}$ i.e Removal of lower yellow leaves at $50 \%$ flowering stage and grain filling stage and two sprays of chlorothalonil 75WP @ 0.15\% (20 g/ 10 lit. water) followed by $\mathrm{T}_{7}$ i.e three foliar sprays of chlorothalonil 75WP @ 0.15\% (20 g/ 10 lit. water) in pooled data. While during all individual years significantly higher yield was recorded in treatment $\mathrm{T}_{6}$ i.e removal of lower yellow leaves at $50 \%$ flowering stage and grain filling stage and two sprays of chlorothalonil 75WP @ 0.15\% (20 g/ 10 lit. water) and was at par with treatments $\mathrm{T}_{7}$ i.e three foliar sprays of chlorothalonil 75WP @ 0.15\% (20 g/ 10 lit. water) and $\mathrm{T}_{4}$ i.e removal of lower yellow leaves at $50 \%$ flowering stage and two subsequent foliar sprays of chlorothalonil 
Amin, A. M. et al. / J. Appl. \& Nat. Sci. 13(1): 191 - 196 (2021)

Table 1. Effect of different treatments on Ramularia blight of fennel.

\begin{tabular}{|c|c|c|c|c|c|}
\hline \multirow{2}{*}{$\begin{array}{l}\text { Sr. } \\
\text { No }\end{array}$} & \multirow[t]{2}{*}{ Treatments } & \multicolumn{4}{|c|}{ Ramularia blight (PDI) } \\
\hline & & 2017-18 & 2018-19 & 2019-20 & Pooled \\
\hline $\mathrm{T}_{1}$ & Removal of lower yellow leaves at $50 \%$ flowering stage & $\begin{array}{c}33.92^{b} \\
(30.67)\end{array}$ & $\begin{array}{l}30.17^{b} \\
(24.80)\end{array}$ & $\begin{array}{l}26.66^{b} \\
(19.67)\end{array}$ & $\begin{array}{l}30.25^{b} \\
(25.04)\end{array}$ \\
\hline $\mathrm{T}_{2}$ & Removal of lower yellow leaves at grain filling stage & $\begin{array}{l}30.53^{c} \\
(25.33)\end{array}$ & $\begin{array}{l}27.23^{c} \\
(20.47)\end{array}$ & $\begin{array}{l}26.07^{b} \\
(19.00)\end{array}$ & $\begin{array}{l}27.94^{c} \\
(21.60)\end{array}$ \\
\hline $\mathrm{T}_{3}$ & $\begin{array}{l}\text { Removal of lower yellow leaves at } 50 \% \text { flowering stage and } \\
\text { grain filling stage }\end{array}$ & $\begin{array}{l}26.89^{d} \\
(20.00)\end{array}$ & $\begin{array}{l}25.71^{\mathrm{C}} \\
(18.33)\end{array}$ & $\begin{array}{l}23.15^{\mathrm{bc}} \\
(15.00)\end{array}$ & $\begin{array}{l}25.25^{d} \\
(17.78)\end{array}$ \\
\hline $\mathrm{T}_{4}$ & $\begin{array}{l}\text { Removal of lower yellow leaves at } 50 \% \text { flowering stage and } \\
\text { two sub sequent foliar sprays of chlorothalonil } 75 \mathrm{WP} @ \\
0.15 \% \text { ( } 20 \mathrm{~g} / 10 \text { lit. water). First spray at just appearance of } \\
\text { disease and second spray at } 15 \text { days after first spray }\end{array}$ & $\begin{array}{l}23.95^{\mathrm{e}} \\
(16.00)\end{array}$ & $\begin{array}{l}20.10^{d} \\
(11.33)\end{array}$ & $\begin{array}{l}19.80^{\mathrm{cd}} \\
(11.00)\end{array}$ & $\begin{array}{l}21.28^{e} \\
(12.78)\end{array}$ \\
\hline $\mathrm{T}_{5}$ & $\begin{array}{l}\text { Removal of lower yellow leaves at } 50 \% \text { flowering stage and } \\
\text { grain filling stage and one spray of chlorothalonil } 75 \mathrm{WP} @ \\
0.15 \% \text { ( } 20 \mathrm{~g} / 10 \text { lit.water }) \text { at just appearance of disease }\end{array}$ & $\begin{array}{l}24.20^{\text {de }} \\
(16.33)\end{array}$ & $\begin{array}{l}20.95^{d} \\
(12.30)\end{array}$ & $\begin{array}{l}20.69^{c d} \\
(12.00)\end{array}$ & $\begin{array}{l}21.95^{\mathrm{e}} \\
(13.54)\end{array}$ \\
\hline $\mathrm{T}_{6}$ & $\begin{array}{l}\text { Removal of lower yellow leaves at } 50 \% \text { flowering stage and } \\
\text { grain filling stage and two sprays of chlorothalonil } 75 \mathrm{WP} @ \\
0.15 \% \text { ( } 20 \mathrm{~g} / 10 \text { lit. water). First spray at just appearance of } \\
\text { disease and second spray at } 15 \text { days after first spray }\end{array}$ & $\begin{array}{l}22.51^{\mathrm{e}} \\
(14.33)\end{array}$ & $\begin{array}{l}17.68^{\mathrm{e}} \\
(8.73)\end{array}$ & $\begin{array}{l}18.53^{d} \\
(9.67)\end{array}$ & $\begin{array}{c}19.57^{f} \\
(10.91)\end{array}$ \\
\hline $\mathrm{T}_{7}$ & $\begin{array}{l}\text { Three foliar sprays of chlorothalonil } 75 \mathrm{WP} @ 0.15 \%(20 \mathrm{~g} / 10 \\
\text { lit. water). First spray at just appearance of disease and sub- } \\
\text { sequent two sprays at an intervals of } 10 \text { days }\end{array}$ & $\begin{array}{l}23.68 \mathrm{e} \\
(15.67)\end{array}$ & $\begin{array}{l}18.07^{\mathrm{e}} \\
(9.13)\end{array}$ & $\begin{array}{c}18.89^{d} \\
(10.00)\end{array}$ & $\begin{array}{l}20.21^{\text {ef }} \\
(11.60)\end{array}$ \\
\hline $\mathrm{T}_{8}$ & Untreated Control & $\begin{array}{l}40.86^{a} \\
(42.33)\end{array}$ & $\begin{array}{c}36.65^{a} \\
(35.17)\end{array}$ & $\begin{array}{l}33.46^{a} \\
(30.00)\end{array}$ & $\begin{array}{l}36.99^{a} \\
(35.83)\end{array}$ \\
\hline & S.Em & 0.88 & 0.56 & 1.25 & 0.57 \\
\hline & C.D at $5 \%$ & 2.66 & 1.71 & 3.80 & 1.60 \\
\hline & C.V\% & 5.36 & 3.97 & 9.26 & 6.40 \\
\hline & $\mathrm{Y} \times \mathrm{T}$ & & & & NS \\
\hline
\end{tabular}

Figures in parentheses are re-transformed value of arc sine transformation; Treatments mean with the common letter (s) are non significant by DNMRT at $5 \%$ level of significance

75WP @ 0.15\% (20 g/ 10 lit. water).

Higher test weight and volatile oil percentage was recorded in treatment $T_{6}$ and which was closely followed by $T_{7}$ and $T_{4}$.Reduction in PDI might be helpful for growing and development consequently seed size and weight(Table 3 ).

On the basis of yield and cost of different treatments; removal of lower yellow leaves at two stages and two sprays of chlorothalonil 75WP @ 0.15\% (20 g/10 lit. water) first at disease appearance and second at 15 days after first spray $\left(T_{6}\right)$ was recorded the maximum yield, gross and net realizations, BCR with lower disease intensity and which was closely followed by $T_{7}$ i.e three foliar sprays of chlorothalonil 75WP @ 0.15\% (20 g/ 10 lit. water) and $T_{4}$ i.e Removal of lower yellow leaves at $50 \%$ flowering stage and two subsequent foliar sprays of chlorothalonil 75WP @ 0.15\% (20 g/ 10 lit. water)(Table 4). Under this study residues level of chlorthalonil 75\% WP @ $0.15 \%$ found below critical limit fix by various agencies (Table 5 ).

Treatment $T_{6}$ i.e removal of lower yellow leaves at $50 \%$ flowering stage and grain filling stage and two sprays of chlorothalonil 75WP @ 0.15\% (20 g/ 10 lit. water ). was found effective not only in terms of management of blight, yield and quality aspects but reduced the load of fungicide on seed which promote the export as compared with our earlier recommendation i.e three foliar sprays of chlorothalonil 75WP @ $0.15 \%$ $(20 \mathrm{~g} / 10$ lit. water). These findings are in agreement with Patel et al. (2016) observed that three sprays of mancozeb 75 WP @ $0.25 \%$ recorded minimum disease intensity, maximum yield, gross and net realizations and BCR which was closely near by spraying of chlorothalonil $75 \%$ WP @ 0.15 per cent. The residues level of chlorothalonil $75 \%$ WP @ $0.15 \%$ was found less than the critical limit fixed by various countries which promote the export of fennel.. Jaiman et. al (2013) recorded minimum Ramularia blight incidence with highest yield with emcarb (mancozeb + carbendazim) @ $0.2 \%$ followed by mancozeb @ $0.2 \%$. Patel and Patel (2008) and Chaudhari and Patel (1987) found mancozeb @ $0.2 \%$ and carbendazim + mancozeb in the reduction of Ramularia blight of fennel. Three sprays of benomyl or tridemorph $0.1 \%$ found the most effective against Ramularia foeniculi of fennel (Lakra, 1993). Sanitation or removal of lower leaves 
Table 2. Effect of different treatments on seed yield of fennel.

\begin{tabular}{|c|c|c|c|c|c|}
\hline \multirow{2}{*}{ Sr. } & \multirow{2}{*}{ Treatments } & \multicolumn{4}{|c|}{ Seed Yield $\left(\mathrm{kg} \mathrm{ha}^{-1}\right)$} \\
\hline & & 2017-18 & 2018-19 & 2019-20 & Pooled \\
\hline $\mathrm{T}_{1}$ & Removal of lower yellow leaves at $50 \%$ flowering stage & $1894^{\mathrm{cd}}$ & $1534^{\mathrm{cd}}$ & $1489^{\mathrm{cd}}$ & $1639^{d}$ \\
\hline $\mathrm{T}_{2}$ & Removal of lower yellow leaves at grain filling stage & $1927^{\mathrm{cd}}$ & $1587^{\text {bcd }}$ & $1584^{\mathrm{bcd}}$ & $1699^{d}$ \\
\hline $\mathrm{T}_{3}$ & $\begin{array}{l}\text { Removal of lower yellow leaves at } 50 \% \text { flowering stage } \\
\text { and grain filling stage } \\
\text { Removal of lower yellow leaves at } 50 \% \text { flowering stage } \\
\text { and two sub sequent foliar sprays of chlorothalonil } 75 \mathrm{WP}\end{array}$ & $1995^{\mathrm{bcd}}$ & $11673^{\mathrm{abcd}}$ & $1635^{\mathrm{bc}}$ & $1768^{\mathrm{cd}}$ \\
\hline $\mathrm{T}_{4}$ & $\begin{array}{l}\text { @ } 0.15 \% \text { ( } 20 \mathrm{~g} / 10 \text { lit. water). First spray at just appear- } \\
\text { ance of disease and second spray at } 15 \text { days after first } \\
\text { spray }\end{array}$ & $2220^{\mathrm{ab}}$ & $1813^{\mathrm{abc}}$ & $1735^{\mathrm{abc}}$ & $1923^{b}$ \\
\hline & $\begin{array}{l}\text { Removal of lower yellow leaves at } 50 \% \text { flowering stage } \\
\text { and arain filling stage and one spray of chlorothalonil }\end{array}$ & & & & \\
\hline $\mathrm{T}_{5}$ & $\begin{array}{l}75 W P @ 0.15 \% \text { (20 g/ } 10 \text { lit.water) at just appearance of } \\
\text { disease }\end{array}$ & $2149^{a b c}$ & $1738^{\text {abcd }}$ & $1699^{\mathrm{abc}}$ & $1862^{\mathrm{bc}}$ \\
\hline & $\begin{array}{l}\text { Removal of lower yellow leaves at } 50 \% \text { flowering stage } \\
\text { and grain filling stage and two sprays of chlorothalonil }\end{array}$ & & & & \\
\hline $\mathrm{T}_{6}$ & $\begin{array}{l}75 \mathrm{WP} @ 0.15 \% \text { ( } 20 \mathrm{~g} / 10 \text { lit. water).First spray at just ap- } \\
\text { pearance of disease and second spray at } 15 \text { days after first } \\
\text { spray }\end{array}$ & $2396^{\mathrm{a}}$ & $1892^{\mathrm{a}}$ & $1946^{a}$ & $2078^{a}$ \\
\hline $\mathrm{T}_{7}$ & $\begin{array}{l}\text { Three foliar sprays of chlorothalonil 75WP @ } 0.15 \% \text { ( } 20 \mathrm{~g} / \\
10 \text { lit. water). First spray at just appearance of disease } \\
\text { and subsequent two sprays at an intervals of } 10 \text { days }\end{array}$ & $2282^{\mathrm{a}}$ & $1861^{\mathrm{ab}}$ & $1822^{\mathrm{ab}}$ & $1988^{\mathrm{ab}}$ \\
\hline $\mathrm{T}_{8}$ & Untreated Control & $1742^{d}$ & $1472^{d}$ & $1323^{d}$ & $1512^{\mathrm{e}}$ \\
\hline & S.Em & 80.62 & 86.87 & 84.37 & 43.77 \\
\hline & C.D at $5 \%$ & 245 & 264 & 256 & 124 \\
\hline & C.V\% & 6.73 & 8.87 & 8.83 & 8.04 \\
\hline & $\mathrm{Y} \times \mathrm{T}$ & & & & NS \\
\hline
\end{tabular}

Treatments mean with the common letter (s) are non significant by DNMRT at $5 \%$ level of significance

Table 3. Effect of different treatments on 1000 seed weight and volatile oil per cent.

\begin{tabular}{|c|c|c|c|}
\hline \multirow{2}{*}{$\begin{array}{l}\text { Sr. } \\
\text { No. }\end{array}$} & \multirow[b]{2}{*}{ Treatments } & \multicolumn{2}{|c|}{ Three years average } \\
\hline & & $\begin{array}{l}1000 \text { seed } \\
\text { weight }(g)\end{array}$ & $\begin{array}{l}\text { Volatile oil } \\
\text { content (\%) }\end{array}$ \\
\hline $\mathrm{T}_{1}$ & Removal of lower yellow leaves at $50 \%$ flowering stage & 6.3 & 1.9 \\
\hline $\mathrm{T}_{2}$ & Removal of lower yellow leaves at grain filling stage & 6.4 & 2.0 \\
\hline $\mathrm{T}_{3}$ & $\begin{array}{l}\text { Removal of lower yellow leaves at } 50 \% \text { flowering stage and grain fill- } \\
\text { ing stage }\end{array}$ & 6.4 & 2.0 \\
\hline $\mathrm{T}_{4}$ & $\begin{array}{l}\text { Removal of lower yellow leaves at } 50 \% \text { flowering stage and two sub } \\
\text { sequent foliar sprays of chlorothalonil } 75 \mathrm{WP} @ 0.15 \%(20 \mathrm{~g} / 10 \text { lit. wa- } \\
\text { ter). First spray at just appearance of disease and second spray at } 15 \\
\text { days after first spray }\end{array}$ & 6.6 & 2.2 \\
\hline $\mathrm{T}_{5}$ & $\begin{array}{l}\text { Removal of lower yellow leaves at } 50 \% \text { flowering stage and grain filling } \\
\text { stage and one spray of chlorothalonil } 75 \mathrm{WP} @ 0.15 \%(20 \mathrm{~g} / 10 \\
\text { lit.water) at just appearance of disease }\end{array}$ & 6.5 & 2.0 \\
\hline $\mathrm{T}_{6}$ & $\begin{array}{l}\text { Removal of lower yellow leaves at } 50 \% \text { flowering stage and grain filling } \\
\text { stage and two sprays of chlorothalonil } 75 \mathrm{WP} @ 0.15 \% \text { ( } 20 \mathrm{~g} / 10 \text { lit. } \\
\text { water).First spray at just appearance of disease and second spray at } 15 \\
\text { days after first spray }\end{array}$ & 6.8 & 2.3 \\
\hline $\mathrm{T}_{7}$ & $\begin{array}{l}\text { Three foliar sprays of chlorothalonil } 75 \mathrm{WP} @ 0.15 \% \text { ( } 20 \mathrm{~g} / 10 \text { lit. wa- } \\
\text { ter). First spray at just appearance of disease and subsequent two } \\
\text { sprays at an intervals of } 10 \text { days }\end{array}$ & 6.7 & 2.2 \\
\hline $\mathrm{T}_{8}$ & Untreated Control & 6.0 & 1.7 \\
\hline
\end{tabular}


Table 4. Economics of different treatments.

\begin{tabular}{|c|c|c|c|c|c|c|}
\hline $\begin{array}{l}\text { Sr. } \\
\text { No }\end{array}$ & Treatment details & $\begin{array}{l}\text { Yield } \\
\mathrm{Kg} \\
\mathrm{ha}^{-1}\end{array}$ & $\begin{array}{l}\text { Gross } \\
\text { Realization } \\
\text { (Rs.) }\end{array}$ & $\begin{array}{l}\text { Cost of } \\
\text { Inputs }\end{array}$ & $\begin{array}{l}\text { Net } \\
\text { Realization } \\
\text { (Rs.) }\end{array}$ & BCR \\
\hline $\mathrm{T}_{1}$ & $\begin{array}{l}\text { Removal of lower yellow leaves at } 50 \% \text { flowering } \\
\text { stage }\end{array}$ & 1639 & 147510 & 45500 & 102010 & 2.24 \\
\hline $\mathrm{T}_{2}$ & Removal of lower yellow leaves at grain filling stage & 1699 & 152910 & 45500 & 107410 & 2.36 \\
\hline $\mathrm{T}_{3}$ & $\begin{array}{l}\text { Removal of lower yellow leaves at } 50 \% \text { flowering } \\
\text { stage and grain filling stage }\end{array}$ & 1768 & 159120 & 46000 & 113120 & 2.46 \\
\hline $\mathrm{T}_{4}$ & $\begin{array}{l}\text { Removal of lower yellow leaves at } 50 \% \text { flowering } \\
\text { stage and two sub sequent foliar sprays of chlorotha- } \\
\text { lonil } 75 W P @ 0.15 \% \text { ( } 20 \mathrm{~g} / 10 \text { lit. water). First spray } \\
\text { at just appearance of disease and second spray at } \\
15 \text { days after first spray }\end{array}$ & 1923 & 173070 & 47900 & 125170 & 2.61 \\
\hline $\mathrm{T}_{5}$ & $\begin{array}{l}\text { Removal of lower yellow leaves at } 50 \% \text { flowering } \\
\text { stage and grain filling stage and one spray of chloro- } \\
\text { thalonil } 75 \mathrm{WP} @ 0.15 \% \text { ( } 20 \mathrm{~g} / 10 \text { lit.water }) \text { at just } \\
\text { appearance of disease }\end{array}$ & 1862 & 167580 & 47200 & 120380 & 2.55 \\
\hline $\mathrm{T}_{6}$ & $\begin{array}{l}\text { Removal of lower yellow leaves at } 50 \% \text { flowering } \\
\text { stage and grain filling stage and two sprays of chlo- } \\
\text { rothalonil } 75 W P @ 0.15 \% \text { ( } 20 \mathrm{~g} / 10 \text { lit. water). First } \\
\text { spray at just appearance of disease and second } \\
\text { spray at } 15 \text { days after first spray }\end{array}$ & 2078 & 187020 & 48400 & 138620 & 2.86 \\
\hline $\mathrm{T}_{7}$ & $\begin{array}{l}\text { Three foliar sprays of chlorothalonil 75WP @ } 0.15 \% \\
(20 \mathrm{~g} / 10 \text { lit. water). First spray at just appearance of } \\
\text { disease and subsequent two sprays at an intervals } \\
\text { of } 10 \text { days }\end{array}$ & 1988 & 178920 & 48600 & 130320 & 2.68 \\
\hline $\mathrm{T}_{8}$ & Untreated Control & 1512 & 136080 & 45000 & 91080 & \\
\hline
\end{tabular}

Table 5. Pesticide residue analysis in different treatments in fennel.

\begin{tabular}{|c|c|c|c|c|c|c|c|}
\hline \multirow{2}{*}{ Tr. } & \multirow{2}{*}{ Treatments } & \multirow{2}{*}{ Results } & \multirow{2}{*}{ LoD } & \multirow{2}{*}{ LoQ } & \multicolumn{3}{|c|}{ Maxi. Residue Limit (ppm) } \\
\hline & & & & & EU & CODEX & Japan \\
\hline $\mathrm{T}_{6}$ & $\begin{array}{l}\text { Removal of lower yellow leaves } \\
\text { at } 50 \% \text { flowering stage and } \\
\text { grain filling stage and two } \\
\text { sprays of chlorothalonil } 75 \mathrm{WP} \\
@ 0.15 \%\end{array}$ & 0.66 & 0.020 & 0.050 & 0.1 & 20 & 5 \\
\hline $\mathrm{T}_{7}$ & $\begin{array}{l}\text { Three foliar sprays of chlorotha- } \\
\text { lonil 75WP @ } 0.15 \%\end{array}$ & 1.25 & & & & & \\
\hline $\mathrm{T}_{8}$ & Untreated Control & BDL & & & & & \\
\hline
\end{tabular}

prevent the introduction of inoculum and to reduce or eliminate the inoculum that is already present at these sites (Palti, 1981). In the present findings, removal of lower leaves helped reducing the inoculum of disease because it starts from lower leaves and disease reduce with one fungicide spray, which helps in lowering the residue level and enhance export promotion.

\section{Conclusion}

Removal of lower yellow leaves at $50 \%$ flowering stage and grain filling stage and two sprays of chlorothalonil 75WP @ 0.15\% (20 g/ 10 lit. water) was found effective not only in terms of management of blight, yield and quality aspects but reduced the load of fungicide on seed which promote the export as compared with our earlier recommendation i.e three sprayings of chlorothalonil 75WP @ 0.15\% first spray at just appearance of the disease and subsequent two spray at 10 days interval. Thus, limited use (2 sprays) of chlorothalonil instead of 3 sprays of mancozeb/ chlorothalonil can be promoted to meet the quality standards of domestic and international market with respect to pesticide residue in fennel.

\section{Conflict of interest}

The authors declare that they have no conflict of interest.

\section{REFERENCES}

1. Abubacker, A. T. N. (2011). Export value of fennel. Spies India. 22:21-22.

2. Anonymous (2019). Spices board of India. Retrieved from http:// www.indianspices.com

3. Chaudhari, S. M. and Patel, A. J. (1987). Chemical control of Alternaria blight and Ramularia blight of fennel. Indian 
Amin, A. M. et al. / J. Appl. \& Nat. Sci. 13(1): 191 - 196 (2021)

J. Mycol. PI. Pathol., 17, 348-350.

4. Datar, V. V. and Mayee, C. D. (1981). Assessment of loss in tomato yield due to early blight. Indian Phytopath., 34, 191-195.

5. Jaiman, R. K., Patel,N. R., Patel,K. D., AgalodiyaA. V., and Patel, P. K. (2013). Management of Ramularia blight in fennel. Int. J. Seed Spices. 3(1), 50-51.

6. Katan, J. (2010). Cultural approaches for disease management: present status and future prospects. J. Plant Pathology, 92(4), 4.7-4.9.

7. Lakra, B.S. (1993). Epidemiology and management of Ramularia blight of fennel. Indian J. Mycol. PI. Pathol., 23,
70-77.

8. Mukerji, K. G. and Basin, J. (1986). "Plant Diseases of India". Tata McGrew Hill Pub. Comp. Ltd., New Delhi. pp. 122-123.

9. Palti, J. (1981). Cultural Practices and Infections Crop Diseases. Springer-Verlag, Berlin, Germany.

10. Patel, D. S. and Patel, S. I. (2008). Management of Ramularia blight of fennel caused by Ramularia foeniculi Sibilla. Indian Phytopath., 61(3), 355- 356.

11. Patel, N.R., Amin, A.M. and Amin, A.U. (2016). Management of ramularia blight in fennel. Int. J. Seed Spices, 6(2) 29-34. 